\title{
Nonverbal Communication Used by Students of Informatics Study Program in Studying English through Lesson Study
}

\author{
Opik Dwi Indah *1, Juwita Crestiani ${ }^{2}$, Muhammad Affan Ramadhana ${ }^{3}$ \\ I, 2, 3 Universitas Cokroaminoto Palopo \\ *opik.dwi_indah@yahoo.com
}

\begin{abstract}
The objective of this research is to know what kinds of nonverbal communication used by the second semester students of Informatics Study Program in studying English at Universitas Cokroaminoto Palopo. This research applied descriptive method. The population of this research is the second semester students of Informatics Study Program class $2 \mathrm{P}$ and $2 \mathrm{~J}$ with the total population is about 70 students. And the participants are 35 students. They were taken by applying purposive sampling technique. In collecting the data, the researcher analyzed the data qualitatively and the instruments used observation checklist and supported by documentation. Based on the observation, the researchers conclude that there are some nonverbal communications that students used in studying English such as: gesture, posture, facial expression and eye contact.
\end{abstract}

Keywords: Nonverbal Communication; Lesson Study

\section{Introduction}

Communication is a fundamental social process and vital in human life. Said to be fundamental for any society man, both primitive and modern, desirous maintain an agreement on a variety of social rules through communication. Told vital because each individual has the ability to communicate with individuals - more people thus increasing the chance that individual to stay alive.

Mulyana (2007) said that communication is the process of exchanging information in the form of massages, symbol, thoughts, signs and opinions. Communication is thus a process by which meaning is assigned and conveyed in a repertoire of skill in interpersonal processing, listening observing speaking questioning, analyzing, gestures, and evaluating, enable collaboration and cooperation.

According to Hybel \& Weaver (2004), the term of communication refers to the interaction with others to share information and beliefs, exchange ideas and feelings, make plans and solve problems. Sometimes this interaction is done interpersonally, in a team or small group, in a conference and sometimes through the media or via computer. We may say that communication consists of transmitting information from one people to another.

\section{Verbal communication}

Verbal is oral statements between people through words and symbols commonly agreed between individuals, groups, nations and countries. It can be concluded that verbal communication is communication using words orally by consciously done by humans to relate to other human beings. A system called the verbal code language. Language can be 
defined as a set of symbols, with the rules for combining these symbols, which is understood and used by a community. Verbal language is the main expression of human's thoughts, feelings, and intentions.

Verbal communication refers to the form of communication in which message is transmitted verbally; communication is done by word of mouth and piece of writing. Objective of every communication is to have people understand what we are trying to convey. In verbal communication remember the acronym (keep is short and simple).

Verbal communication is further into: oral communication and written communication. In oral communication, spoken words are used. It includes face to face conversations, speech telephonic conversation, video, radio, television, voice over internet. In oral communication, communication is influence by pitch, volume, speed and clarity of speaking. In written communication, written sighs or symbols are used to communication message can be transmitted via email, letter, report, memo etc. In written communication, it is influenced by the vocabulary and grammar used, writing style, precision and clarity of the language used.

\section{Nonverbal communication}

Nonverbal communication is the sending or receiving of wordless messages. It is all about the body language of speaker such as gesture, body language, posture, tone of voice of facial expressions.

There are three things to remember in nonverbal communication, interpretation is a critical characteristic of nonverbal communication, Nonverbal communication is not a language of its own system, but more a part of the system of verbal, nonverbal communication can easily misinterpreted. Despite the verbal and nonverbal communication is different in many thing, but both forms of communication that often cooperate or in other words, nonverbal communication has a specific function in verbal communication. The main function of nonverbal communication is as a repeater to say verbally, as complement the verbal message, as a substitute to represent verbal communication, emphasis on certain words.

Various movements of the human body are different can be made as a signal to nonverbal communication, but in this section only have some basic movements that many people use. Gestures also included as a signal in nonverbal communication. What is meant by the gesture is a movement of the body, head, hands, and feet that are meant to convey a particular message.

Gestures have an important role in communication because can be a substitute and complement verbal language. Language movement the body can be translated directly into a word or phrase; for example, the speaker raised his thumb upwards, which means good, raised both shoulders does not know, and others.

In most cultures, eye contact is one the most immediate form of communication and received. Eye contact has the function of which is to see the feedback, to let people another that the channels of communication open and be able to speak, sign of natural relationship. To avoid misinterpretation, a sign language submitted must unambiguous, precise and understandable manner universal. Therefore, sign language used in airsoft game in sign language adaptation of the military that has prevailed internationally.

Nonverbal communication helps receiver interpreting the messages received. Often, nonverbal communication signal reflect the situation more accurately than verbal message. Nonverbal communication have the three elements: I). Appearance: speaker (clothing, hairstyle, neatness, use of cosmetics) and surrounding (room size, lighting, decorations, 
furnishings); 2). Body language: facial expressions, gestures and postures; Ana 3). Sounds: voice tone volume speech rate.

\section{Forms of nonverbal communication}

According to Burgoon in Nordquist (1998), seven different nonverbal dimensions: (I) kinesics or body movements including facial expressions and eye contact; (2) vocalics or paralanguage that includes volume, rate, pitch, and timbre; (3) personal appearance; (4) our physical environment and the artifacts or objects that compose it; (5) proxemics or personal space; (6) haptic or touch; and (7) chronemics or time. To this list we would add signs or emblems.

Bi Jiwan (2012) divided nonverbal communication into four type: body language, paralanguage, object communication, and physical environment. Body language refers to designation for instinctive, conscious and conventional expressive movements of the body, including posture, head movements, facial expressions and gesture and so on. Paralanguage, sometime called vocalic, is the study of nonverbal cues of the voice. It includes voice quality, emotion, and speaking style, as well as prosodic features such as rhythm, intonation, and stress. These paralanguages my change the meaning of words.

Nonverbal communication can be communicated by object communication. An object communication includes clothing, hairstyle, architecture, symbols and so on. Physical environment also has influence on communications behaviors. However, this environment is not research about natural environment. It includes furniture, architecture style, interior decorating, lighting condition, colors, temperature, noise, and music. Also proxemics and chromatics also are physical environments. All physical environment factors may affect the behaviors of the communicators during interaction.

\section{The function of nonverbal communication}

The communication function generally according to Mulyana (2010) in his book Science communication worldview an introductory quote William I. Gorden regarding communication functions as follows:

\section{Repetition}

Repetition or recurrence occurs in when verbal has the same meaning with nonverbal. That is to reproduce the intent conveyed from verbal communication. Nodded his head when he said "yes," or shaking his head when he said "No."

\section{Accentuation}

Accentuation or pressure is the use nonverbal cues to reinforce verbal meaning. For example, using hand gestures, tone of voice slowed when speech.

\section{Complement}

Here nonverbal communication has a function to complement the verbal message. But in contrast to the substitution of complement. Verbal and nonverbal codes each adding meaning to each other. Tone of voice, gestures and body movements can indicate feelings of a person who completes a verbal message.

\section{Contradictions}

Contradictions can occur when verbal and nonverbal messages contradict. Often, these functions happen by accident. The function of this contradiction is usually used when satirical or humor. Verbal message stating one meaning, but nonverbal language to express feelings 
that felt real. Such as someone praised the achievements of his friend but he shoot out the lip.

\section{Substitute}

Nonverbal communication here has a function to convey a message when someone does not use verbal language. In some instances, nonverbal messages that are intended to function very clear. For example, someone compliments something just with thumbs-up without using the word.

\section{Regulation}

In this function nonverbal communication tasked to monitor and control when interacting with someone. Examples such as when giving eye contact when talking to someone.

In this research, the researchers focus to conduct a research about nonverbal communication used by the students when they study English in the classroom. Nonverbal communication is an activity of sending and receiving messages without using words, spoken and either has a greater influence for daily life. This communication is to convey a message with the body movements, facial expressions, eye contact and vocal quality. Nonverbal cannot separated with verbal communication because has benefits that are equally important with verbal communication. This is because of the nonverbal communication with verbal communication work together in the communication process.

This research is done through lesson study activities. As stated by Hiebert at al. (2002) that lesson study is the process of improving and building knowledge in teaching process that has origin in Japanese elementary education. To make sure in this research, lesson study is proposed for university classroom. There are various stages of lesson study but in this study the research applied three stages, they were plan, do and see. In the plan stage, the lecturer (the researcher) and other lecturers with the same discipline planned the teaching together was done in doing stage. In this stage, the researcher open the class to be observed by some observers (other lecturers) after having the teaching process, the next step is see (reflection) where in this case the researcher and the observer shared their reflection during the teaching and learning process they have observed.

\section{Method}

This research was conducted from $7^{\text {th }}-31^{\text {st }}$ May 2018 at Universitas Cokroaminoto Palopo. The population was the second semester students of Informatics Study Program from class $2 \mathrm{P}$ and 2J. The total number of participants is about 70 students. The technique in choosing the sample was purposive sampling. The researcher took only one class that was class $2 \mathrm{P}$ which consist of 35 students. The researchers took this class because that class was taught by the researcher. Moreover, that class is more active and has many of the students than class 2] which is only has 29 students.

This research used observation sheet. Observation sheets used to determine the kinds of nonverbal communication used by second semester students of Informatics Study Program which focused on the students' kinesics. The researcher took photos and video as a documentation during teaching and learning process.

\section{Results}

In this research, the researchers used descriptive qualitative method to find out what kinds of nonverbal communication used by students in English learning and how do the student's use the nonverbal communication in the English learning in the classroom. 
Based on the observation, the researchers found kinds of nonverbal communication that the students used in studying English.

Table I. Students' Nonverbal Communication in the classroom

\begin{tabular}{|c|c|c|c|}
\hline \multicolumn{2}{|c|}{ Nonverbal communication } & \multirow{2}{*}{$\begin{array}{l}\text { Yes } \\
\checkmark\end{array}$} & \multirow[t]{2}{*}{$\mathrm{No}$} \\
\hline Gesture & Nodding the head & & \\
\hline & Raising the hand & $\checkmark$ & \\
\hline & Folding the hand & $\checkmark$ & \\
\hline \multirow[t]{3}{*}{ Posture } & Bowing the head & $\checkmark$ & \\
\hline & Rigid body & & \\
\hline & Slumped posture & $\checkmark$ & \\
\hline \multirow[t]{6}{*}{ Facial expression } & Fear & $\checkmark$ & \\
\hline & Shock & $\checkmark$ & \\
\hline & Smile & $\checkmark$ & \\
\hline & Angry & & $\checkmark$ \\
\hline & Sad & & $\checkmark$ \\
\hline & Shy & $\checkmark$ & \\
\hline \multirow[t]{4}{*}{ Eye contact } & Gazing & $\checkmark$ & \\
\hline & Intense eye & & $\checkmark$ \\
\hline & Winking & & $\checkmark$ \\
\hline & Glancing & $\checkmark$ & \\
\hline
\end{tabular}

From the results of the research above, the researcher concludes that the nonverbal communication used by the students in the classroom through lesson study is nodding the head, raising the hand, folding the hand, head bowed, rigid body, slumped posture, fear, shock, smile, shy, gazing and glancing when they studied English and there are only 4 nonverbal communications that are not used in the classroom by the students such as angry, sad, winking and intense eye. Those expressions are related with facial expression and eye contact.

\section{Discussion}

Based on the finding above, it can be seen the kinds of nonverbal communication used by the students in English learning the classroom. The students was more interested in using kinesics in students' English learning. As the researcher has stated previously that the observation has done in one month and the researchers have analyzed the kinesics of nonverbal communication that the students used. For the specific purposes that have been provided below:

\section{Students' gestures}

From the results of the study, the researchers concluded that the nonverbal communication used by students in the classroom were nodding the head, rising and folding the hand. Those students did the movements without realizing in their communication during studying English. Students fold their hand for paying attention to the lecturer's explanation, make a nod head when they understood and raised their hand if they wanted to ask or answer lecturer's question.

Those nonverbal communications used by the students related to Tabensky's statement (2002). He states that gestures are movements of the body, especially the hand or arms, 
they express an idea or emotion. When they raised their hand, they express their ideas and when they nod their head, they showed their emotion that they have understood.

\section{Students' posture}

Based on the analysis in the classroom, there were some students using nonverbal communication in the classroom such as head bowed, rigid body slumped posture when the lecturer explained.

Knapp \& Hall (2010) said that posture relates to body movements and to height, or tallness, still carries powerful message of dominance. There is some evidences of height being positively correlated with success in leadership positions. Just as people are often unhappy with their overall body image, some are unhappy with their height and may try to compensate (very tall people may stoop while short people may hold their body more erect to appear taller). To lower body towards someone else as in a shallow or deep bow is a universal sight respect and sometimes event defeat. Aggression can be shown by a rigid body, with shoulders raised, both signals of readiness for physical combat. Defeat or depression are indicated by a slumped posture, representing both humility and retreat to the helplessness but recalled security of the focus.

Based on the observation, students showed their aggression by representing their rigid body. Moreover, when they felt depression, their posture of body was slumped. Posture can affect the students in learning process and also their position in sitting. If the seat is good, not too low, not too big, round, rectangle length, according to the student body will feel comfortable and can learn calm and posture cue the students sit silent in English Learning in class. If it is not got, they will slump their body. It means that, they felt depressed or uncomfortable.

\section{Students' facial expression}

Some facial expressions that the students used in the classroom are fear, surprise, smile and shy. The expression of fear and surprise that the students used when lecturer explained the materials and asked the students, their facial expressions changed. It indicates that they have not understood with what is explained by the lecturer. And they were smile and shy when they asked and wanted to answer the lecturer's question. It indicates they doubt to with their answer or they knew but they were shy to answer.

Morris (2002) said that the face reveals much of our emotional disposition, and there are strong culture and social massages involved in suppressing or expressing those emotions. Facial expressions are one way to convey an emotional because feelings or emotions and their facial expressions are usually difficult to hide. They are related to each other. Students' emotion can affect students in learning process and also their facial expression. If they felt happy or enjoy, they will express smile face. But, if they felt uncomfortable they will show their fear expression in their face. During studying English, they never felt angry or sad.

\section{Students' eye contact}

One might argue that eye contact is an important means of nonverbal communication used in the classroom because the first thing that the lecturer and students do before they start teaching learning process is looking or gazing to each other. It is relevant with Morris (2002), he states that eyes the "portals of the soul", communicate fundamental messages, sometimes consciously, sometime unconsciously.

The exchange of eye contact forms a kind of background for further communication. Three main functions can be associated with eye contact in the classroom. The first function 
is the examination of understanding. Thus, the effective way lecturers can check students' understanding is through eye contact. In this case eye contact can be an efficient way to check understanding. Usually, students, unknowingly, look ahead as they understand what is being explained.

The second, the students will glance when they did not understand. They tend to keep eye contact when they understand, and drop it when they do not understand. This fact is corroborated by the findings of this research. An important thing to mention here is that eye contact itself is not a valid measure to check understanding. The third, eye contact also can help the students to retain their interest. Lecturer, like other public speakers, need to retain their audiences' interest until the end of the session. Sometimes most of the students like to see the lecturer but not always. Based on the findings, the students never winked their eyes to show their interest or showed their intense eye to show their domination. They just gazed and glanced.

\section{Conclusion}

Based on the discussion, the students used not only verbal, but also nonverbal communication in studying English in the classroom through lesson study. Some nonverbal communication used are gesture, posture facial expressions, and eye contact. For that reason, the researchers suggest the lecturers to know kinds of nonverbal communication did by their students, so they can know well what students feel and want when they are studying English in the classroom.

\section{References}

Bi Jiwan. (20I2). Teori Komunikasi (Theories of Human Communication). Jakarta: Salemba Humanika.

Hybel, S. \& Weaver, R. (2004). Communication Effectively, $7^{\text {th }}$ Edition. New York: McGraw-Hill. Knapp, M.L., \& Hall, J. (20 I0). Nonverbal Communication in Human Interaction ( $\left.7^{\circ} \mathrm{Ed}\right)$. Boston: Wadsworth/Cengage Learning.

Barker, L. (20I0). Verbal and nonverbal indices of learning during problem-based learning (PBL) among first year medical students and the threshold for tutor intervention. Medical Lecturer, 32.

Mulyana, D. (2007). Ilmu Komunikasi: Suatu Pengantar. Bandung: Remaja Rosadakarya.

Pan, Q. (2009). Nonverbal lecturers-students communication in the foreign language classroom. Theory and Practice in Language Studies, 2(12), Pp. 262-232.

Sugiono. (20I I). Metode Penelitian Pendidikan (Pendekatan Kuantitatif, Kualitatif dan R\&D). Bandung: Penerbit Alfabeta.

Tabensky, A. (2002). Gesture and speech rephrasings in conversation. Gesture, I(2), Pp. 213-236. https://doi.org// 0.1075/gest.1.2.07tab 